\title{
Optimizing Utilization of Petroleum Coke in Nigerian Metallurgical Industry
}

\author{
E.J. Akpabio* and O.W. Obot** \\ *Chemical \& Petroleum Engineering Department, Faculty of Engineering, University of Uyo, \\ Uyo, Nigeria. Email:ejakpabio@yahoo.com \\ **Mechanical Engineering Department, Faculty of Engineering, University of Uyo, Uyo, \\ Nigeria. Email: obotowo2004@yahoo.com
}

\begin{abstract}
Utilization of petroleum coke in the rejuvenating Nigerian metallurgical industry is currently satisfied by importation from more industrialized nations of the world such as the USA, Brazil and Venezuela where delayed coking plants operate and grow in number. The sad years of poor planning have revealed lapses in integration and synergic planning of our industrial complex. The sources of petroleum coke feedstock have been identified and confirmed as atmospheric and vacuum residues of Nigerian refineries. Analysis has portrayed a symbiotic relationship between the metallurgical industry as one of the major end users of various petroleum coke grades, the shot coke, the sponge coke and the needle coke, and the petroleum industry on its part benefiting while providing ready market for steel sheet metals for even coke drum manufacture. This effort shall greatly increase the Nigerian content in these key industrial sectors, with the resultant reduction in capital flight through importation, if rethinking, and re-strategizing are injected into our industrial planning, and revamps models. Redesign options of existing refineries and reengineering of newly proposed refineries should contain resid processing units such as Delayed Coking Plant which will deepen conversion of residual petroleum feed stocks and produce various petroleum coke grades for utilization in power generation sector and our growing metallurgical and electrode industries.
\end{abstract}

Key words: petroleum, coking, plant, ore, residue, cracking

\section{INTRODUCTION}

Kudrin [1] indicates that in countries with relatively weakly developed industry and a low stock of metals in use, the charge of steel making plants consists mainly of pig iron (or products of direct conversion of iron from iron ores). Pig iron smelted in blast furnaces is graded as foundry iron, conversion iron and blast furnace ferro-alloys, the main mass being produced as conversion iron which is converted into steel in steel making plants. Among the grades of conversion iron 
depending on its composition and smelting condition, is coke pig iron, open-hearth pig iron grades M1 and M2, high quality-charcoal pig iron grades etc.

An accelerated rate of economic development of Nigeria was much noticed at the era of oil boom, as observed by Kotov [2] when the country received 100 billion dollars in all for oil export.

The "petro-dollar", as the boom money became known and called, brought in its wake a sudden expansion of infrastructure: construction of roads, bridges, sea ports and air ports, hydroelectric stations, etc. Processing industry was developed at high rate and the construction of metallurgical complexes was started at that time. Also, metallurgical research centres were sited in the country to give a high technical support to the metallurgical industries located at Ajaokuta in Kogi State, and Aladja in Delta State, with the rolling mills at Oshogbo, Katsina and Jos to name a few of the down-stream iron and steel works.

Although the actual production of iron and steel at the scale envisaged by the Nigerian government in the early 1980s has not been achieved, yet with the skeletal production, Kotov [2] estimated that in 1990 the steel consumption per capita was $45 \mathrm{~kg}$ and that the projected value was to grow by $6 \%$ annually. The raw materials requirement of a metallurgical industry is usually very high and in the Nigerian case, has both the local and foreign components. Unamba [3] noted that it was the availability of huge reserves of the local raw materials namely: iron ore concentrate, coal, limestone, clays, natural gas, water, etc. that supported government initiative to establish and run the iron and steel industries. Of all raw materials for iron and steel smelting, coal in the form of coke is the chief source of fuel.

\subsection{Metallurgical Coke Properties and Production Problems in Nigeria}

Wikipedia [4] defines coke as a solid carbonaceous residue derived from low-ash, low-sulphur bituminous coal. The volatile constituents of coal (including water, coal-gas, and coal tar) are driven off by baking in an airless oven at temperatures as high as $1000^{\circ} \mathrm{C}$, so that the fixed carbon and residual ash are fused together. Here coal is the major raw material of coke production. Ephimenko [5] describes the coking process and confirms the parameters used.

This solid, coked mass is formed on intensive heating of various fuels to a temperature range of $900-1100^{\circ} \mathrm{C}$ in the absence of air. Coking process is carried out in coke furnace chamber which in form is a parallelepiped of $400-500 \mathrm{~mm}$ in width, in which the coke charge, an average mixture of diverse coals comminuted to about $0-3 \mathrm{~mm}$ is fed. The coke chamber is isolated from atmosphere but connected only to the trapping apparatus for the volatile components liberated from the coke charge.

\subsection{Quality of Metallurgical Coke}

Coke properties can be divided in to three major groups namely: Chemical, Physico mechanical and Physico - chemical, Table 1. 
Table: 1. Metallurgical Coke Properties

\begin{tabular}{|c|c|c|}
\hline $\mathrm{S} / \mathrm{No}$ & Indicators & Properties \\
\hline \multirow[t]{6}{*}{1.} & $\begin{array}{l}\text { Chemical composition } \\
\text { (Organic), } \%\end{array}$ & $C^{*}, 96.5-97.5$ \\
\hline & & $\mathrm{H}, 0.5-0.8$ \\
\hline & & $\mathrm{O}, 0.3-0.4$ \\
\hline & & $\mathrm{S}$, trace \\
\hline & & $\mathrm{N}$, trace \\
\hline & & $\mathrm{P}, 0.02-0.04$ \\
\hline & (Inorganic), \% & $\operatorname{Ash}\left(\mathrm{SiO}_{2}, \mathrm{Al}_{2} \mathrm{O}_{3}, \mathrm{Fe}_{2} \mathrm{O}_{3}\right), 9-20$ \\
\hline & & Moisture, $3-8$ \\
\hline & & Volatile matter $0.8 \leq 1.5$ \\
\hline \multirow[t]{3}{*}{2.} & Physico - mechanical & $\begin{array}{l}\text { Strength, \% mass after comminution }>25 \mathrm{~mm} \text { (M } 25 \text { index) } \\
<10 \mathrm{~mm}(\mathrm{M} 10 \text { index })\end{array}$ \\
\hline & & Porosity, pore volume $35-55 \%$, for blast furnace $50 \%$ \\
\hline & & Specific mass, $430-500 \mathrm{~kg} / \mathrm{m}^{3}$ \\
\hline \multirow[t]{2}{*}{3.} & Physico - chemical & Combustibility, $650-700^{0} \mathrm{C}$ \\
\hline & & Reactivity $\mathrm{R}^{* *}$ \\
\hline
\end{tabular}

$\mathrm{C}^{*}$ - determined relationship $\mathrm{C}_{\mathrm{nv}}=100-(\mathrm{VM}+\mathrm{A}+\mathrm{S})$

Where: $\mathrm{C}_{\mathrm{nv}}$ - Carbon non- volatile; VM - Volatile Matter; A - Ash; S - Sulphur $\mathrm{R}^{* *}$ - determined from the reaction according to this equation: $\mathrm{C}+\mathrm{CO}_{2} \rightarrow 2 \mathrm{CO}$

$$
\mathrm{R}=\left\{\mathrm{CO} /\left(2 \mathrm{CO}_{2}+\mathrm{CO}\right)\right\} * 100 \%
$$

The coke quality is determined by the quality of coking coal. Table 2 indicates the major characteristics of coke from selected regions of the world.

Table2: Chemical Composition of Selected Metallurgical Coke

\begin{tabular}{|c|c|c|c|c|c|c|c|c|c|}
\hline & & & & Tech & cal Anal & sis, $\%$ & & & \\
\hline $\mathrm{S} / \mathrm{Nc}$ & Coal & Region & $\begin{array}{l}\mathrm{C}_{\mathrm{NV}}, \\
\%\end{array}$ & Ash & Moistur & $\begin{array}{l}\text { Yield of } \\
\text { volatile } \\
\text { matter }\end{array}$ & $\mathrm{S}, \%$ & $\mathrm{P}, \%$ & $\begin{array}{l}\text { Total } \\
\text { Porosity, \% }\end{array}$ \\
\hline 1. & $\begin{array}{l}\text { Durham } \\
\text { (England) }\end{array}$ & Cleveland & 88.0 & 10.0 & 3.0 & $0.9-1.2$ & 1.0 & 0.01 & 52 \\
\hline 2. & Rur (FRG) & Rur & 88.0 & 10.0 & 4.0 & $1.0-1.2$ & $0.9-1.2$ & 0.02 & 48 \\
\hline 3. & $\begin{array}{l}\text { Cornnel } \\
\text { (USA) }\end{array}$ & Pittsburgh & 88.8 & 9.8 & 4.9 & $1.0-1.2$ & 0.95 & 0.02 & 47.56 \\
\hline 4. & $\begin{array}{l}\text { Donetsk } \\
\text { (USSR) }\end{array}$ & Donetsk & 87.3 & 9.6 & 3.2 & $0.9-1.1$ & 1.7 & 0.02 & $49-52$ \\
\hline 5. & Kutznets & Ural & 86.5 & 11.9 & 3.5 & 1.0 & 0.58 & 0.04 & 40 \\
\hline
\end{tabular}

Source: Metallurgiya Chuguna, Ephimenko [5]. 
Nigeria is richly endowed with other natural resources like iron ore with the largest deposit at Agbaja in Kogi State with over 1 billion tons reserves, and then the vast reserve of coal at Enugu and its environs. The mining of coal at Enugu has been a major source of revenue for Nigeria as far as export market is concerned. However, it must be noted that local consumption of coal in Nigeria has been limited due to absence of major consumers. Whereas the Nigerian Railway Corporation and Power Holding Company of Nigeria plc had been key consumers, the iron and steel sector consumption would have surpassed that of all other sectors put together. This is buttressed by the fact that about $400-500 \mathrm{~kg}$ of coal is needed for the production of 1 ton of pig iron [5].

A typical coke has a specific gravity in the range 1.85 - 1.9. Its properties of high porosity and smoke-free make coke a highly desirable fuel suitable for stoves and furnaces. Coke is used as fuel and as a reducing agent in smelting of iron ore in the blast furnace. Coke from coal is grey, hard, and porous. Historically, the use of coke as a fuel was pioneered in $17^{\text {th }}$ century England in response to the ever-growing problem of European deforestation. Wood was becoming increasingly scarce and expensive, and coals fumes, particularly smoke and sulphur components, disqualified it from many applications, including cooking and iron smelting. In 1603, Sir Henry Platt suggested that coal might be charred in a manner analogous to the way charcoal is produced from wood. This process was not put into practice, however, until 1642, when coke was used for roasting malt in Derbyshire. In 1709, Abraham Darby set up a coke-fired blast furnace to produce cast iron.

\section{METHODOLOGY}

Analytical survey and critical studies of the historical and operational data of the Nigerian petroleum refining industry and the metallurgical industry were conducted using industrial data, as well as information from published literature and reports. The sources of materials acting as supporting or auxiliaries in the metallurgical, specifically iron and steel industry were identified and a key role was allotted to petroleum coke. The useful coke grades obtained in coking processes have not been produced in Nigeria. Earlier studies have shown potentials of coking operations with Nigerian residual products, beginning from vacuum residue mixed with some atmospheric residue to the very heavy products with no qualitative utilization.

Metallurgical industry which provides a ready market for this peerless valuable petroleum product, coke, has witnessed a disastrous unfolding of event. Optimizing the raw materials potential, productivity and consequently utilization of petroleum coke in Nigerian metallurgical complexes is a desire of every Nigerian and this paper tries to stimulate the scenarios that would lead to the realization of these lofty aspirations.

\section{ANALYSES AND DISCUSSIONS}

\subsection{Petroleum Coke Production and Utilization}


In contrast to metallurgical coke which is produced from coal, petroleum coke is produced from heavy petroleum residues e.g. Vacuum residue and other asphalteno-resinous materials in thermal cracking process called delayed coking. The global trend in refinery revamps programmes has the following keywords - flexibility to handle the changing supply of crude from light to heavier. Heavy crudes are cheaper than sweet crudes due to their limited processing capacity. Delayed coking is one of the major additions and targets for upgrades for the processing of the bottom-of- barrel into lighter products such as gasoline and other distillates. Table 3 highlights the basic properties of feedstocks for petroleum coke production in Delayed Coking Plant.

Table 3: Characteristics of Typical Delayed Coking Feed Stocks

\begin{tabular}{|l|l|l|l|l|}
\hline Indicators & $\begin{array}{l}\text { Residue stock } \\
\text { Kotur-Tepe } \\
\text { Crude }\end{array}$ & $\begin{array}{l}\text { Cracking } \\
\text { Residue } \\
\text { Volgograd } \\
\text { crude }\end{array}$ & $\begin{array}{l}\text { Cracking Residue } \\
\text { Tatar crude }\end{array}$ & $\begin{array}{l}\text { Residue Stock and } \\
\text { asphalt of Fergana } \\
\text { Crude }\end{array}$ \\
\hline Specific gravity, $\rho_{4}^{20}$ & 0.958 & 0.920 & 1.026 & 0.993 \\
\hline $\begin{array}{l}\text { Conradson Carbon } \\
\text { Residue, \% }\end{array}$ & 9.2 & 6.5 & 21.2 & 14.3 \\
\hline Content, \%: & \multicolumn{5}{|l|}{} \\
\hline Sulphur & 0.47 & 0.55 & 2.92 & 0.62 \\
\hline Ash & 0.08 & 0.10 & 0.12 & 0.10 \\
\hline Group Composition, \% & \multicolumn{5}{|l|}{} \\
\hline Total oil & 68.6 & 83.0 & 58.5 & 67.0 \\
\hline $\begin{array}{l}\text { Including paraffin } \\
\text { waxes }\end{array}$ & 5.9 & - & - & - \\
\hline Resins & 5.9 & 14.0 & 26.9 & 25.5 \\
\hline Asphaltenes & 29.9 & 2.5 & 14.4 & 7.5 \\
\hline Carbenes and carboides & - & 0.3 & 0.2 & - \\
\hline
\end{tabular}

Source: Adapted from Erikh et al. [6]

According to [7], adding a Delayed Coking Unit to a refinery flow scheme provides a two-fold financial incentive: (1) cheaper feedstock and (2) a higher volume of light products. Delayed coking is a process in which a heavy residual feedstock is superheated and then introduced into an insulated, vertically oriented cylindrical pressure vessel, the coking chamber or coke drum. Vapours are then removed to be further processed into various petroleum by-products, leaving behind, a high-density hydrocarbon residue referred to as petroleum coke. 


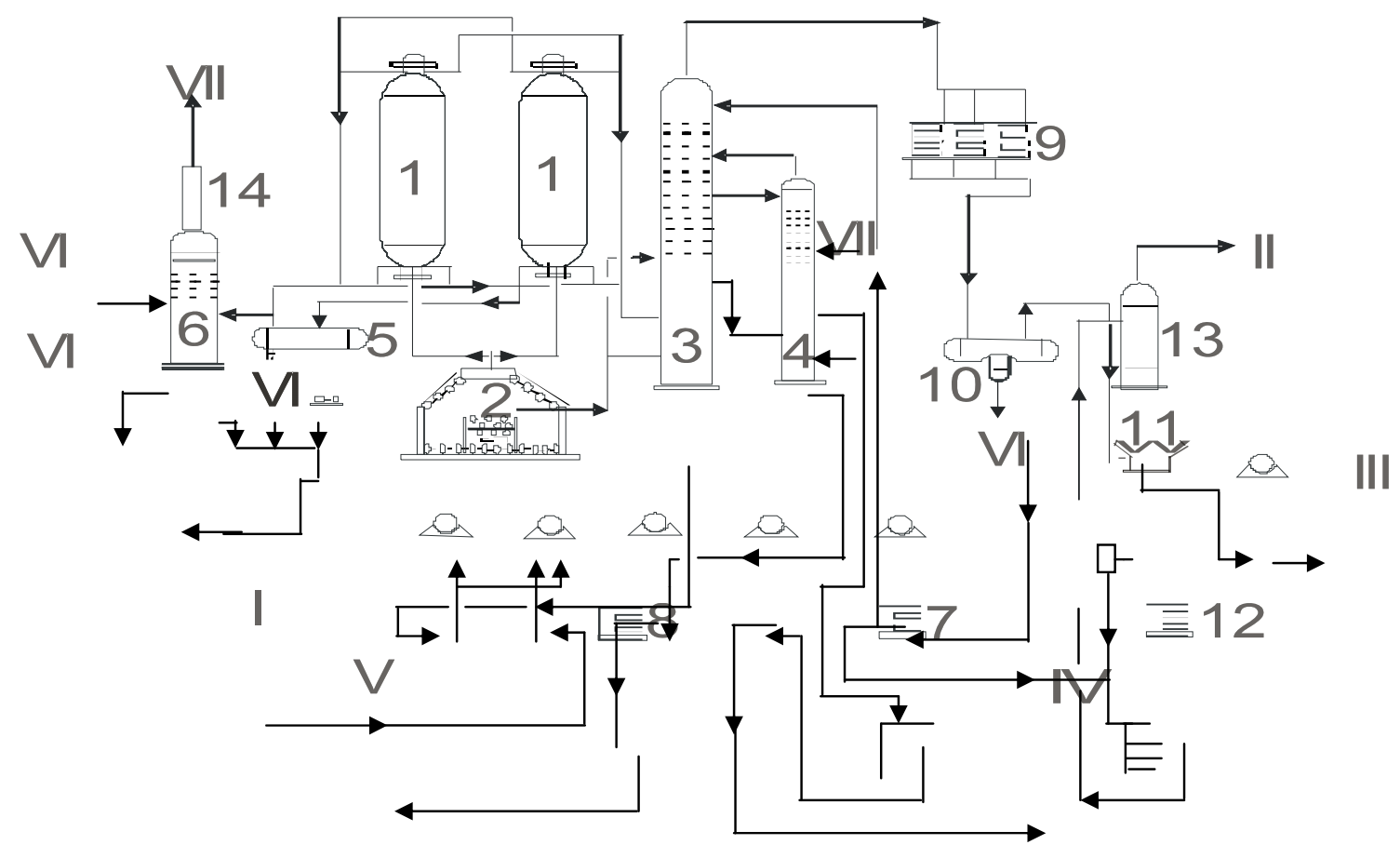

Fig. 1: Typical Flow Diagram of Delayed Coking Plant

Equipment: 1. Coke drum, 2. Furnace, 3. Rectification column, 4. Stripping column, 5. Condensate collector, 6. Drum for chamber air blowing, 7. Kerosene cooler, 8. Gasoil cooler, 9. Condenser, 10. Reflux accumulator, 11. Compressor, 12. Terminal cooler, 13. Gas separator, 14. Steam and gas vent

Lines: I. Feed, II. Gas, III. Gasoline, IV. Light gasoil, V. Heavy gasoil, VI. Water, VII. Steam

Petroleum coke has many uses besides being a fuel. Marketable coke is coke that is relatively pure carbon and can be sold for use as fuel in the manufacture of dry cells, ferro-alloys, carbon and electrodes, etc. Needle coke, also called acicular coke, is a highly crystalline petroleum coke used in the production of electrodes for steel and aluminium industries. The high heat and low ash of petroleum coke make it a good fuel for power generation in coal-fired boilers, but petroleum coke from high sulphur crude residues and low in volatile content poses some environmental and technical problems with its combustion.

Since 1991, the global petroleum coke output has grown by $4 \%$ p.a and is expected to rise from $83 \mathrm{mt}$ (including 59mt marketable coke) in 2001 to more than $88 \mathrm{mt}$ by the end of 2005 . This figure could be exceeded as $13.5 \mathrm{mtpy}$ of new or expanded capacity could come on stream during this period. Growth in North America (3.3\% p.a) and Europe (1.4\% p.a) is below the world average but this is balanced by significant expansion in Asia (about $8 \%$ p.a). There are many reasons why the global demand for petroleum coke is expected to rise significantly even beyond the end of 2006. Firstly, it is observed that the global consumption of oil and oil-related products 
shows no sign of nose-diving, and this tendency will usher in increased productivity in the sector. Secondly, it should be noted that there is the decreasing quality of crude oil feed stocks, and the higher demand for gasoline and other transportation feeds. Thirdly, the progressively stringent environmental regulations for these fuels will lead to a greater need for coking. Also according to [4], globally, around $75 \%$ of petroleum coke output is burned as a fuel: in North America, around $90 \%$ of coke used in the energy sector is catalyst coke that is burned as fuel in its host refinery. In Europe and the Pacific region, non-energy applications (including electrodes and cement manufacture) are proportionately more important. The manufacture of carbon and graphite electrodes is the largest non-fuel end-use for petroleum coke, which is the main ingredient in carbon anodes for primary aluminium smelting and in graphite electrodes for steel production via the electric arc furnace (EAF) process. Furnace linings in ferrous and non-ferrous industries are yet another application of petroleum coke [8].

\subsection{The Role of Petroleum Refining and Metallurgical Industries in Promoting Nigerian Content}

According to Kotov [2] the potential of oil mining in Nigeria makes up 120mtpy. There are four refineries with a total output of $23 \mathrm{mtpy}$. Since Nigeria is one of the world major oil producing countries, by implication, it means quite a lot of petroleum coke should be produced in the country for local use and export. However, data available does not show this to be the case, as Asuquo [9] maintains that 80,000 tons of petroleum coke per annum required by the Aluminum Smelter Company of Nigeria (ALSCON) was to be imported initially from Germany, USA or Great Britain, etc. Further, he shows that NNPC conducted a detailed study which indicated that Bonny medium crude oils were suitable for producing premium quality petroleum coke and pitch. However, the production of petroleum coke in Nigeria and pitch could not be undertaken due to the absence of Delayed Coking Plant and indigenous customers.

In the metallurgical industry, coke is a vital requirement, an embodiment of energy input, as far as the blast furnace smelting is concerned. Petroleum coke has about 5\% application in the blast furnace operation according to Kudrin [1], and in electric arc furnace (EAF) smelting, it has an excellent application and the tendency is growing at an encouraging rate. According to [4], consumption in EAF steel making could rise to $1.65 \mathrm{mt}$ by 2005 , although continuing advances in electrode technology and efficiency could reduce this slightly. It further asserts that by far the biggest national producer of petroleum coke is the USA, which accounts for $61 \%$ of global output and $51 \%$ of capacity. The recent exploits of oil sands in the Orinoco Belt region of Venezuela will have added 6.2 million tones per year of petroleum coke capacity, making Venezuela the second biggest petroleum coke producer.

The Nigerian iron and steel sector ought to have been a major consumer of petroleum coke, were the key metallurgical complexes to be operational. Kotov [2] confirms that the Delta Steel Works, for instance, with an installed capacity of 1 million tones of Billets per year has electric furnace shop with 4 No electric arc furnaces of 110 tons each. The electric furnace shop merely operated at $13-15 \%$ of its capacity and this was mainly due to lack of raw materials and consumables, chiefly because they were not available at home market. Besides above, electric 
power, a home generated major component was also deficient. Had the Nigerian Metallurgical Industry fully taken off as was expected, the EAF smelting would have led to intensification of petroleum coke production first for local consumption, and, of course, for export as a foreign exchange earner. However, with ALSCON coming on board as a local consumer of petroleum coke, local manufacture of petroleum coke would make more meaning.

Regrettably as it is, petroleum coke is largely an un-finished product, a colossal waste, a huge loss of foreign exchange to Nigeria. It is hoped that the policy makers and government have got to address the above situation with a view to:

* Revamping the iron and steel sector and repositioning it for maximum productivity in the $21^{\text {st }}$ century.

* Establishing petroleum coke production plants, as petroleum coke is fast becoming a cost efficient alternative to coal.

Table 4: Dependence of Coke Quality on Temperature of the Delayed Coking Feedstock.

\begin{tabular}{|l|l|l|l|}
\hline \multirow{2}{*}{ Indicators } & \multicolumn{3}{|l|}{ Feedstock heating temperature, ${ }^{\circ} \mathrm{C}$} \\
\cline { 2 - 4 } & $490{ }^{\circ} \mathrm{C}$ & $500{ }^{\circ} \mathrm{C}$ & $510{ }^{\circ} \mathrm{C}$ \\
\hline Yield of the Volatiles, \%(mass) & 10.0 & 7.8 & 6.8 \\
\hline Temporary resistance to pressing, $\mathrm{kgf} / \mathrm{cm}^{2}$ & 50 & 80 & 100 \\
\hline Apparent density, $\mathrm{g} / \mathrm{cm}^{3}$ & 0.70 & 0.85 & 0.95 \\
\hline Porosity, \% & 50 & 40 & 33 \\
\hline
\end{tabular}

Source: Bannov[10]

\subsection{Possible Uses of Various Petroleum Coke Grades in Metallurgical Industry}

\subsubsection{Shot coke}

The production of shot coke in a delayed coker requires high concentrations of asphaltenes in the feedstock, dynamics (velocity and/or turbulence) in the coke drum, and high coke drum coke temperatures.

Normally, small shot coke balls from different delayed cokers will be nearly the same size; however, Mexican Mayan VRC has been found to produce larger shot coke balls upon delayed coking than does Venezuelan VRC. It is thought that smaller balls are made when very high feeds rates are used in the coker. Aromatic feeds, such as decant oil from the FCCU, can help eliminate shot coke formation.

Shot coke is unique in that the small spheres two to five millimeters in diameter each have a slick shiny exterior coating of needle or acicular type carbon. When rapidly heated in a calcining kiln, the outer layer is cracked and pulled away from the center; thus when used in an anode with a coal tar binder, the binder adheres to the outer layer (egg shell). This results in many cracks 
between the ball and the skin causing the anode to crack and dust in an aluminium smelter cell [11].

\subsubsection{Sponge coke}

Sponge coke is named for its sponge-like appearance and is produced from VRC with a low to moderate asphaltene concentration. If sponge coke meets strict property specifications, it is considered anode grade sponge coke suitable for calcinations for use in making carbon anodes for the aluminium industry. Otherwise, if sponge coke meets the more lenient fuel grade specifications, it can be used in its raw form for fuel.

The biggest problem for refineries producing anode grade sponge coke is obtaining the low volatile matter (VM) required. Raw or 'green' sponge coke must be calcined before it can be used in making anodes. The density of the calcined coke is critical for producing good carbon anodes. The higher the density, the more carbon can be incorporated into the anode, and the longer the anode will last. Vibrated bulk density (VBD) of the calcined coke must be greater than 86 (grams/100cc). The best single property that correlates from the raw coke is the Hardgrove Grindability Index (HGI). Raw coke with lower than 70 HGI usually can be calcined to produce an $86 \mathrm{VBD}$. Volatile matter is another good property used to correlate how well the raw coke will calcine. Structure is a strong factor in calcinability also, since cokes with low CTE must have volatile matter much lower than a more isotropic type coke to produce the same density. Porosity of the calcined coke should be low and is also a function of the raw coke volatile matter. The ash of the calcined coke is normally around $0.2 \%$ with vanadium and nickel combination under 500ppm. Sodium and calcium are very strong catalysts for air burn of an anode. Vanadium, nickel and iron and other metals cause increased carboxyl reaction in the bottom of the anode. The sulfur in the anode must be below 3.5\% to prevent the sulfur from increasing the electrical resistance of the cast iron connection between the anode and the power rod. Normally, sulfur is more of an environmental and scrubbing problem. Sulfur can cause the real density of calcined coke to decrease due to an increase in the porosity and micro cracking of the calcined coke. Sulfur does help reduce reactivity (air and carboxyl) by reacting with the caustics which are strong catalysts.

Aluminum production requires around one-half kilogram of carbon per kilogram of aluminum produced. Anode grade coke must be low in metals concentration since the exhaust from the aluminum cell is being scrubbed with the alumina used as feed to the aluminum cells. Therefore, any metals in the coke would get into alumina and into the aluminum metal produced. The carbon is used in the aluminum smelter as a means of carrying electrical power into the cell. It takes around $15 \mathrm{KW}$ of power per $\mathrm{kg}$ of aluminum produced. A carbon with some porosity must be used since gases coming off the cell would block the power going into the cell if the anode was not porous. The high temperature along with the very corrosive fluoride salts used in the aluminum cell and the problem with the evolution of the gases makes the discovery of a nonconsumable anode difficult.

\subsection{The Role of Petroleum Coke in the Production of Graphite Electrodes}




\subsubsection{Needle coke}

Needle coke, named for its needle-like structure, is produced from feedstocks without asphaltenes present, normally FCCU decant oils. Needle coke is the premier coke, used in graphite electrode manufacturing (used in steel arc furnaces) and commands a high price (calcined ultra-premium non-puffing, $\$ 500$ per ton). Most needle coke is produced from hydrodesulfurized decant oil (due to the low sulfur requirement for non-puffing coke, that can be nearly flash graphitized in the new direct current (DC) length-wise graphitization method, without splitting the electrode). Needle coke must have low sulfur $(<0.6 \mathrm{wt} \%)$ and nitrogen contents in order to be non-puffing during graphitization to $2900^{\circ} \mathrm{C}$ (measured by a special dynamic puffing test that is proprietary). Needle coke must also have a maximum amount of coarse sizing $(>6 \mathrm{~mm})$, a minimum amount of fines $(<1 \mathrm{~mm})$, good density $(>78 \mathrm{grams} / 100 \mathrm{cc}$; $4 / 6$ mesh test), low ash content $(<0.3 \%$; any ash leaves a void when graphitized), and a high real density (2.13 grams/cc).

Most graphite plants want a needle coke with low variability so that they can set up the optimum pitch level, extruding and baking to produce a good electrode. The most popular electrode is the 24 inch $(60 \mathrm{~cm})$, with a demand for larger than $30 \mathrm{inch}(76 \mathrm{~cm})$ for DC single electrode furnaces. Obtaining good needle coke is still a 'black art' for excellent graphite electrodes. The principal property that the electric arc steel mill wants in a graphite electrode is a low amount of graphite per ton of steel melted. In single electrode DC furnaces, the amount of graphite per ton is below $2 \mathrm{~kg} /$ ton. With better practices and foamy slag, AC furnaces (using three electrodes due to threephase electric power) have approached this level.

\subsection{Metallurgical Content in Delayed Coking Plant}

Wodnik and Hughes [12] opined that grassroot cokers are often designed with larger sized coke drums than those found in older facilities. Coke drums are now up to $30 \mathrm{ft}$ in diameter and $96 \mathrm{ft}$ tall, (tangent-to-tangent length). This broad mass of metallic structures opens a wide market for iron and steel products in Nigeria if coker plants are installed in our refineries, and create a symbiotic relationship between the petroleum processing and the steel making industries. Coke is produced and sold to the metallurgical industry while steel sheet metals are being sold to the refining industry for delayed coker drum manufacture.

Delayed coking is an open technology. In fact, the coke drum manufacture involves nothing other than correct selection of metal and adequate welding techniques which can be done by Nigerian engineering team. The outside of the drum is insulated with around $10 \mathrm{~cm}$ of fibreglass insulation with aluminium or stainless steel covering. Since coking is an endothermic process, heat must be conserved from complete reaction [11].

Other residual treatment operations and the uses of their end products are shown in Table 5, and only Delayed coking process produces petroleum coke used in the metallurgical industry. 
Table 5: Resid Processing Options and End Uses

\begin{tabular}{|l|l|}
\hline \multicolumn{1}{|c|}{ Process } & \multicolumn{1}{c|}{ Products uses } \\
\hline Visbreaking & $\begin{array}{l}\text { Reduces viscosity of the oil, with production of some heavy } \\
\text { gasoil. }\end{array}$ \\
\hline Resid Hydrocracking & $\begin{array}{l}\text { Feed contacted with catalyst and hydrogen at high temp and } \\
\text { pressure resulting in removal of S.N and some aromatics, } \\
\text { conversion to lighter oil. }\end{array}$ \\
\hline Residuum FCC & $\begin{array}{l}\text { Metals in feedstock quickly deactivate catalyst, must use } \\
\text { passivators to reduce undesirable reactions. }\end{array}$ \\
\hline ROSE & $\begin{array}{l}\text { Residual Oil Supercritical Extraction produces metal free } \\
\text { gasoil, asphaltene and resins. }\end{array}$ \\
\hline Propane Deasphalting/ bright stock & $\begin{array}{l}\text { Solvent Extraction of heavy lube oils. } \\
\text { Road asphalt, roofing asphalt fuel oil. }\end{array}$ \\
\hline Delayed Coking & $\begin{array}{l}\text { Deepens conversion into lighter liquid products produces } \\
\text { petroleum coke for metallurgical and electrode industry as } \\
\text { well as fuel grade coke. }\end{array}$ \\
\hline
\end{tabular}

\section{CONCLUSION AND RECOMMENDATIONS}

The paper has demonstrated that non production of petroleum coke has been a painful economic waste to Nigeria as a direct result of insufficient planning in the oil and gas sector. Whereas the end products derivable from petroleum coke production include carbon, ferro-alloys, electrodes etc. which would have become raw materials or consumables for Aluminum Smelter Company and the metallurgical industries, as local contents, are still in many cases imported. The paper advocates that Delayed Coking plants where our local residual feedstocks would be used in producing the various coke grades, shot coke, sponge coke and needle coke locally, which are currently imported into the country, should be built in the country to reduce capital flight, create employment and stimulate the downstream sector participation.

Nigeria should simultaneously develop the two complimentary industries and gain from both of them both quantitatively in profit making and qualitatively in enhancing Nigerian content and participation [13].

Refiners over the world in order to remain competitive are cashing on establishing such plants as the delayed coking unit with its two pronged benefits of flexibility in feedstock processing capability and additional liquid products. Already, the difference in crude oil prices between heavy and light crudes in the range of US \$ 4-10 per barrel is sufficient gain for industries processing heavy crude. The progressive processes of deepening the conversion of our crude oil such as the Delayed Coking are well studied for economic viability [14]. 
Nigerian engineers and engineering personnel have the capacity to design more complex structures, even the coke drum. Give them a chance to make their input into this downstream sector equipment manufacture and maintenance contracts.

\section{REFERENCES}

1. Kudrin, V., Steel Making, Mir Publishers, Moscow, 1985.pp 4-89

2. Kotov K. I., The Importance of Metallurgical Industry in a Developing Economy School Metallurgy and Materials Technology, Federal Polytechnic Idah, 1993.

3. Unamba, E. A., The Importance of Iron and Steel Industry in Nigeria (Nigerian Metallurgical Society, Ajaokuta, Public Lecture, Federal Polytechnic, Idah), 1993.

4. Petroleum Coke. 6 December, 2010 from http//en.wikipedia.org/wiki/petroleum coke.

5. Ephimenko, G. G, Metallurgia Chuguna, Kiev, 1988 pp $18-28$

6. Erikh, V. N., Rasina, M. G. and M. G. Rudin (1988) The Chemistry and Technology of Petroleum and Gas, Mir Publishers, Moscow, pp 186-202.

7. Stewart, C. W., Stryk Aaron M. and L. Presley (2006) Coke Drum Design. Petroleum Tech. Quarterly, vol. 3 pp. 63-69.

8. Bhaskara Rao B. K., Modern Petroleum Refining Processes $2^{\text {nd }}$ Ed., Oxford IBH Publishing Co., New Delhi, 1990. Pp 320-405

9. Asuquo, L. O., The Importance of Aluminum Smelter Plant in Nigeria. Metallurgical Society and TIAZJPROMEXPORT Specialists, Federal Polytechnic Idah, 1993.

10. Bannov P. G., (2001) “ Protsesy pererabotkiy Nefti, Chast II”, KINEF, Moscow, pp 24-28

11. Ellis, Paul J. and Paul Christopher A. (2000) Tutorial: Delayed Coking Fundamentals. AIChE $3^{\text {rd }}$ International Conf. on Refining Processes. Atlanta, Georgia USA.

12. Wodnik, R. and Hughes G. C. (2005) Delayed Coking Advances. Petr. Tech. Qtly, Q4. pp. $35-45$.

13. Akpabio Emmanuel J. (1989) M.Sc. Eng. Thesis. Design and Development of Delayed Coking Plant of Capacity $1.32 \mathrm{mln}$ tonnes per annum. AZINEFTEKHIM, Baku, USSR.

14. Akpabio, E. J., Oghenejoboh, K. M. and Neeka J. B. (2006) Prospects of Integrating Delayed Coking Plant into the Nigeria Refinery Flow Scheme. Proc. of International Conf. on Engineering Research and Development, UNIBEN, Benin City, Nigeria, pp 544-548. 